\title{
IMMIGRATION AND LIBERTARIANISM: OPEN BORDERS VERSUS DIRECTIONALISM
}

\section{J. C. Lester}

Independent, London, UK

https://orcid.org/0000-0002-3795-4612

OMESTE

JEL Category: P140

\begin{abstract}
To explain the correct libertarian approach to immigration, a thought-experiment posits a minimal-state libertarian UK and then the introduction of several relevant anti-libertarian policies with their increasingly disastrous effects. It is argued that the reverse of these imagined policies, as far as is politically possible, must be the correct way forward. This framing is intended to counter the tendency for many articles to misapply libertarian principles to the current messy situation on the mistaken assumption that a state need only stop interfering without rectifying or adjusting for its previous interferences. The relevant parts of various open-border texts are then criticised in light of this and for other errors, in particular for overlooking the likely huge scale of immigration as indicated by Gallup surveys. Additional criticisms are addressed in footnotes throughout. The conclusion outlines three broad options on immigration and suggests that directionally-libertarian policies are both more libertarian and practical than having states open their borders. The readers that might be interested in this subject matter include those engaging in libertarian philosophy, economics, and political theory.
\end{abstract}

Keywords: libertarianism; immigration policy; philosophy; private property; open borders; directionalism; thought-experiment

\section{INTRODUCTION}

There has long been a debate in the libertarian literature as to the correct state policy on

The address of the author:

J. C. Lester

䤵jclester@gmail.com

${ }^{1}$ A review suggests that a couple of paragraphs would have sufficed here. That might be so for most libertarians, but for those people largely unacquainted immigration. This essay does not attempt a comprehensive account and evaluation of all the different arguments in that vast debate. It primarily compares directionally-libertarian policies with the open-borders option. It does this by first assuming, arguendo, a functional minimal-state UK and then how this might relevantly be undermined. ${ }^{1}$ The inference is then made and defended that the reverse of this, as far as is practical, must be the

with libertarianism (the vast majority) that would probably not give an adequate picture. 
correct libertarian policy. Without such a libertarian framing there seems to be a tendency for many articles to misapply libertarian principles to the current messy situation. Next, various crucial parts of open-border texts are responded to in light of this argument and for other errors. This appears to be sufficient to constitute a prima facie refutation of open borders (a state with no immigration restrictions) ${ }^{2}$ and defence of directionally-libertarian policies.

\section{WORKING BACKWARDS FROM AN IMAGINED SOLUTION}

Imagine that the UK has become a rapidlydeveloping, minimal-state, libertarian country. ${ }^{3}$ This includes having the airports, ports, and all of the roads being privately owned, maintained, operated, and policed. Some roads have fairly undiscriminating access, especially where they have retail outlets that want to attract custom. Many roads are gated and guarded because the owners ${ }^{4}$ don't want the nuisance or security-risk of people coming in uninvited. Thoroughfares have been negotiated, or court-imposed on libertytheory ${ }^{5}$ principles, to ensure access around the country.

Many people around the world want to move to libertarian-UK. Some of these people are invited to come to specific places to work. Other people meet the residency requirements to move into certain areas. And some come in as sponsored guests or tourists with personal or business guarantors that are liable for any necessary security costs or fines if any leave-dates are exceeded. There is a wide variety of similar options.

\footnotetext{
2 A review objects that this essay "does not even rigorously define the key terms that it debates". Only if there is a significant possibility of confusion might a few clarificatory words be useful (but that is not to fall into the essentialist error of trying to "define" words, let alone "rigorously"). Does this "lead to a crucial flaw" namely, "an implicit contrast between private property rights and open borders"? The contrast is of a state having restricted versus unrestricted immigration. It is biased to assert only that "immigration restrictions are always opposed to libertarian principles". They are opposed to some but defend others, because public property ought to be owned by the populace.
}

However, there are many more people who would like to move to libertarian-UK but they haven't been invited. Consequently, there are variouslyfunded private barriers and security measures to stop them. These are at airports, ports, along the coast, and as elaborate as seems desirable. A relatively small number of people do still manage to sneak in by some means, but it's not worth increasing airport and border security beyond a certain economic point. In any case, even after gaining entry, those people find that they still cannot go or live just anywhere they choose: there are private gates, barriers, and security systems across the entire country. Consequently, they either tend to be caught eventually (and fined, or put to work in prison to pay the fine, before being expelled) or they manage to become unobtrusive, productive members of the areas to which they have gained access. Peace, security, and everincreasing abundance pervade the land. According to libertarians, at least, this is a model society - if not yet an anarchy - that the rest of the world can observe and, if they wish, emulate.

Then something unforeseen happens. The new government decides to compulsorily purchase all of the roads, ports, airports, and coastal security in order, says the prime minister, to "hold and maintain them in trust for the citizenry". He assures us that a "very modest and temporary increase in overall taxation" (currently at around $5 \%$ of GNP) is all that is initially needed to cover their purchase then upkeep and operation at current standards. He confidently predicts that there will be "economies of scale due to having sole public ownership" (i.e., a state monopoly); hence "overall taxes will soon go down to lower than before". Many people have their doubts that

${ }^{3}$ A review asks why the UK is used and suspects a tendentious motive. Clue: the British spelling and the use of "we" anent the U.K.

4 These will likely be the people living nearby with some procedure for deciding such things, or some company looking to offer what its main customers prefer.

${ }^{5}$ On the abstract theory of libertarian liberty and how its application implies property rules, see Lester (2021). In more detail see the relevant chapters or indexes in Lester ([2000] 2012); ([2011] 2016); (2014). 
the free market has missed such alleged "economies of scale", but it doesn't seem worth most people's while to campaign against this and they think that just maybe they will save some money eventually.

After a year or two overall taxation has risen beyond the "very modest and temporary increase", and that still doesn't appear to be enough (quelle surprise!). Rather than try to raise taxes still further, the prime minister announces that "in the interests of economy and the free movement of UK residents" he will be removing all of the gates and guards from UK roads. Many people are resentful of this. Some of them observe that such an argument could be used to remove people's front doors so that anyone might enter their homes. ${ }^{6}$ There ensues a significant increase in various crimes now that no UK resident can be denied access to any street in the country-with the mysterious exception of Downing Street, which remains gated and policed.

After another year or two the prime minister announces that "in the interests of economy and freedom of migration" he is removing all relevant border security from around the country, and its ports, and airports. In the following months many millions of people from around the world flood into the country. (According to Gallup data, ${ }^{7}$ around 34 million people would come to the UK if possible as their first choice now; but presumably many more would actually choose to come if the UK alone had an open border). As economics implies, immigrants inevitably keep on arriving up to the

\footnotetext{
${ }^{6}$ A review implies that there is not "even one libertarian proponent of open borders who also favors abolishing private property rights in this way". All open-border libertarian texts that do not advocate prior privatisation are in effect "abolishing property rights" for the legitimate owners of public property: the existing populace.
}

7 Esipova et al. 2018.

8 A review objects that this is "hypothesizing ridiculous scenarios [and] then taking them as standards for evaluating the real world". As the disaster scenario appears (probably to most people) to be what would be likely to occur with open borders, it seems reasonable to assume it; and its likelihood is certainly explained. The review continues, "the entire example consists of unproven assertions and groundless claims about point that the UK is no better-all things considered by them-than the places from whence they come; and many of those places are awful for a variety of reasons. All of the country's parks and squares have become shanty towns. All kinds of crime and other social problems are rife and increasing (far exceeding any problems that have been reported in Germany and Sweden, for instance, with relatively tiny recent immigration increases). Many native people have left the country and more are preparing to leave. Someone shot dead the prime minister, and the remaining native population celebrated. But there is no going back. ${ }^{8}$

What are we to make of this thought-experiment from a libertarian viewpoint? Everything the imagined government has done has been a move away from a libertarian society. This appears to suggest that the full libertarian policy now, in our real not-so-bad situation, should be to do the reverse of this thought-experiment and privatise everything among the existing population. But clearly that is not yet politically possible. Currently, all the roads, immigration controls, etc., are in effect held in trust (and maintained and operated at taxpayer expense) by the state on behalf of the existing citizens; or, at least, that is the only halfreasonable excuse the state could offer. And, as opinion polls consistently show, an overwhelming majority of the existing citizenry want controlled immigration. ${ }^{9}$ Therefore, on no libertarian-account should the state do the very opposite of this and open the borders. It's hard to see how allowing the country to fall to third-world standards-as

economic and social decline, which are not even explained, let alone justified." As all arguments and evidence rest on assumptions they logically amount to assumptions. Therefore, "assertions" cannot be "proven" given a "ground" or "justified". However, they can be conjecturally explained and defended from criticism; and critically preferred if this appears to be successful. And this is what this essay does, despite the strange claim that they are "not even explained". The review fails to critically engage with the actual explanations, arguments, and defences. It merely complains that there is no supporting justification-as though such a thing were possible.

9 In fact, most probably want current immigration rates reduced (Migration Watch UK 2019). 
opening the borders would ineluctably, eventually, cause-could have good long-run consequences even for most of the new immigrants or the rest of the world. ${ }^{10}$ This is especially so because there is the very obvious libertarian alternative of practicing full free trade with the poor regions of the world and thereby raising their living standards to something that would relatively soon approach that of wealthier countries, and maybe even exceed it if they were themselves to become more libertarian than we currently are-which is not a very high bar to reach.

All of this might seem fairly obvious to many libertarians. However, some libertarian texts argue that the state should immediately have open borders for libertarian and humanitarian reasons. A variety of criticisms of open borders are dealt with in these texts. And some of the given answers are to varying degrees sound. However, they don't deal adequately-if at all-with the disaster scenario explained here, and they often commit significant other errors. A few relevant points and conclusions from some of these texts will now be criticised.

\section{RESPONSES TO SOME OPEN- BORDER ADVOCACIES}

All of the essays or authors cited here might have been dealt with at considerably greater length, even up to exclusive essays for each. But it seems more useful to cite what appear to be the crucial problematic passages and take a more

10 A review mistakenly alleges that the "discussion assumes throughout that the arrival of immigrants is a net drain on the economy and leads to net decline (stated clearly on [this page])." So where is the quotation? No such assumption is made or implied. The account given here is dealing with open borders, not limited immigration. Of course limited immigration can be beneficial on balance. Perhaps it is the review that is perpetrating a "kind of bait-and-switch move" by extrapolating the beneficial effects of limited immigration to unlimited immigration.

11 A review complains that this approach doesn't "develop [its own] criticisms" or address "the bulk of the arguments" in the articles. But the criticisms are as long as seems sufficient to make the relevant points and the "bulk of the arguments" are either not particularly relevant or not disagreed with. comprehensive approach. ${ }^{11}$ In any case, verbum sapienti satis est. ${ }^{12}$

\section{Block 1998}

When there is virgin territory, there is no legitimate reason for immigrants (or domestic citizens) to be prevented from bringing it into fruitful production. (174)

The "domestic citizens" would already have taken over this land had they been, as they should, allowed to do so. Instead, they have been prevented-to their ever-compounding loss-and this has also been enforced to some extent at their own expense through taxation. This appears to be sufficient to give them a prior, restitutional, libertarian claim to be allowed to take it (issuing tradable shares to all citizens is one possible, if imperfect, solution). By small-scale analogy, suppose the state had long ago declared its ownership of the last third of everyone's gardens-where people have them, and before they have "homesteaded" them ${ }^{13}$ - and mandated that these be left untouched for "environmental reasons". The owners of the rest of the gardens would otherwise have taken them, and they have been greatly inconvenienced by not being allowed to do so. Hence, they should now have first claim to them. It is not libertarian to allow what are, predominantly, non-victims in either case to engage in a sort of land rush. ${ }^{14}$

... either migration is totally legitimate, in which case there should be no interferences

12 A review objects to difficult language, especially Latin, in a scholarly essay. O tempora, o mores. Verb. sap. is the mot juste, and some reviews are on the wrong side of it.

13 If necessary, assume that the state had "homesteaded" them by "by first capturing worms and bugs and mice, elsewhere, and then setting them loose" (Block 2019, footnote 19).

${ }^{14} \mathrm{~A}$ review asserts that this is "implicitly [...] assuming that all land was previously claimed. But this is not realistic for massive amounts of state-controlled land around the world". But all non-private land has been state-claimed, and otherwise it would by now mostly have been claimed by citizens. Only where it possibly would not (Polar regions, deserts, etc.) is there a case for non-citizen, first-user ownership. 
with it whatsoever, or it is a violation of the non-aggression axiom, in which case it should be banned, fully. I have argued in this paper that the former position is the only correct one. (185)

Immigration, in particular, is neither "totally legitimate" (in libertarian terms) nor totally a "violation". In a fully libertarian society, there would be no state borders and so no overall immigration control as such; there would be only private-owner control of entry. But when we have the state owning buildings, roads, 'national' parks, etc., supposedly on behalf of the existing populationas we currently do-then a compromise is all that is possible in practice. And given the utter disaster of open borders for the existing population, having some restrictions on immigration is more libertarian-however imperfect this is compared to a fully libertarian ideal.

\section{Block and Callahan 2003}

the profit motive, if nothing else, will lead to the mass invitation of foreigners to our shores. (67)

"Mass invitation of foreigners" into private property alone is not the problem. The problem is a devastating deluge of uninvited foreigners also coming into territory that is in effect held in trust for the existing population. If there are 'open borders', then no invitations are required. People can simply escape a less-desirable country by entering a known much better one. In the UK some immigrants do start as beggars, but beggars in a richer country.

Hoppe maintains that in the present context the U.S. government is in effect a manager for the private property owners who live within the borders of the country. We maintain, in contrast, that the state cannot properly take on any such role. (67)

Correct, it cannot do it "properly", i.e., efficiently and according to libertarian principles. But it can do a better job or a worse job, and allowing

${ }^{15}$ A review objects that "all of the authors [...] just cited in defense of open borders have spent their entire careers showing quite clearly that states cannot protect us in this way". They have occasionally published unlimited immigration is close to doing the worst possible job.

States Higgs in this regard: "[...] If the state cannot legitimately create borders in the first place, because its very existence is illegitimate, then it manifestly cannot promulgate just rules with regard to how open or closed any such borders will be." (67-68)

Correct, the state cannot provide fully "just rules". But open borders are even more unjust than restrictions that prevent a libertarian and welfare disaster.

\section{Gregory and Block 2007}

there is no way for government immigration controls to keep out the "uninvited," let in the "invited," or even determine who would fall into each category. The state simply cannot mimic the market, and directing its coercive mechanism in such an attempt will prove ineffective in achieving desired goals, wasteful of wealth created in the private sector, and destructive to liberty. (25)

All completely true. But it misses the big picture, which is one of utter libertarian and welfare disaster. The state can, and currently does, protect us from that. ${ }^{15}$

Inevitably, of course, immigration controls violate the property rights of those inside, as well as outside, [...] who wish to exchange with each other, and who can indeed maintain the costs of the immigrant's stay. (38)

Then some type of sponsorship may be one morelibertarian way to deal with that. "Inevitably, of course, [having no] immigration controls violate [what ought to be] the property rights of those inside"-up to the point of national disaster (i.e., a disaster for the people that comprise the actual nation, not necessarily a disaster for the state).

\section{Caplan 2012}

Proponents of immigration restrictions have to show why, moral appearances

articles defending open borders. For the reasons given, these articles fail as regards "showing quite clearly" that open borders are better than prior privatisation among citizens, and failing that cautious immigration controls. 
notwithstanding, immigration restrictions are morally justified. (20)

As all arguments rest on assumptions, and thereby amount to assumptions, there are no supporting justifications. ${ }^{16}$ However, immigration restrictions here appear to be moral because they are more libertarian and avoid a national disaster. Therefore, "proponents of [abolishing] immigration restrictions have to show why, moral appearances notwithstanding, immigration restrictions are [not] morally [defensible]".

Most Americans benefit from immigration, and the losers don't lose much. (20)

Because the unlimited deluge of immigrants is not allowed.

Immigration restrictions are not necessary to protect American culture. ... [or] to protect American liberty. (21)

As long as very limited numbers can immigrate.

Even if all these empirical claims are wrong, though, immigration restrictions would remain morally impermissible. Why? Because there are cheaper and more humane solutions for each and every complaint. If immigrants hurt American workers, we can charge immigrants higher

16 For explanations of critical rationalist epistemology see, for instance, Popper [1963] 1978 and Miller 1994. A review asks, "So what exactly are the authors trying to do with their own arguments? Isn't their disaster scenario intended to justify opposition to open borders?" This essay is intended to conjecturally explain and defend why there should be a critical preference for not simply opening state borders. That is not a naïve attempt to "justify".

${ }^{17}$ A short piece elsewhere, Caplan 2014, assumes that Puerto Ricans are a good model for how immigration is typically likely to be. However, as the various comments on this point out, inter alia, Puerto Rico "is classified as a high income economy by the World Bank", "The central argument for supporting the idea 'swamping' will occur is the ease of transportation today", and "New Yorkers considered the Puerto Rican influx a major contributor to the decline in New York City in the third quarter of the 20th Century".

${ }^{18} \mathrm{~A}$ review found it "bizarre" that this essay had formerly cited a 2012 poll and claims that "trends have shifted dramatically in many countries since 2012 ". In fact, this taxes or admission fees, and use the revenue to compensate the losers. (21)

Any "admission fees" would be prior to admission and thereby a form of immigration restriction.

If immigrants hurt American culture, we can impose tests of English fluency and cultural literacy. (21)

Any prior "tests of English fluency and cultural literacy" would be a form of immigration restriction.

Whatever your complaint happens to be, immigration restrictions are a needlessly draconian remedy. (21)

All of this simply overlooks the big picture. Assuming that there are no immigration restrictions, then all policies-libertarian and otherwise-would simply be swept away by the tide of incoming people. ${ }^{17}$ The same Gallup survey as cited earlier shows around 160 million foreigners had the U.S. as their first preference for migration now (not that they might want to migrate to the U.S. at some future time if the conditions sufficiently improve in some way). ${ }^{18}$ And even more would initially want to come if the U.S. alone opened its borders. However, they would only keep arriving until the U.S. were no better, all things considered by them, than where they were

more recent poll states that "The countries where potential migrants say they would like to move-if they could-have generally been the same for the past 10 years" (Esipova et al. 2018). But there is now a 10 million increase for the U.S. since the 2012 poll: "Nearly 160 Million People Want To Move To The U.S." (McCarthy 2018). The review then argues that “presumably Gallup didn't poll [all of these] people, so there may be issues in the estimates they provide". The survey methods are explained as follows: "These results are based on aggregated telephone and face-toface interviews with 453,122 adults, aged 15 and older, in 152 countries from 2015 to 2017 . One can say with $95 \%$ confidence that the margin of sampling error for the entire sample, accounting for weighting and sample design, is less than \pm 1 percentage point." Next, the review objects that this is to "ignore the possibility that anything other than disaster can pause the flow of immigrants". Like what? Without a suggestion it is hard to reply. We are also told that this ignores the "relevant comparison: [...] the two most preferable locations, wherever those might be". Ex hypothesi, there is only one country with open borders. 
coming from. ${ }^{19}$ And that might happen well before all of them were to arrive. ${ }^{20}$

\section{Huemer 2010}

In a late-added footnote, Huemer 2010 notices a similar earlier Gallup survey and merely observes (without citing any evidence): "most of these individuals have not made an observable effort to migrate to the U.S". ${ }^{21}$ When there are not open borders that is probably because most of them would rightly regard this as almost certainly a wasted effort. By analogy, many film stars' fans might like to move in with their favourite star but "most of these individuals have not made an observable effort" (and some of the few that have were arrested). However, in light of the possibility of a disastrous influx, Huemer 2010 does "grant that it may be wise to move only gradually towards open borders". But why not, instead, move quickly to giving the citizens the roads, buildings, land, etc., they ought to own so that no state borders will be necessary?

Heumer 2010 summarises its arguments in the conclusion:

\footnotetext{
19 If immigration to the U.S. would continue until the U.S. is no better (all things considered by the potential immigrants) than the places from whence the immigrants come, then why doesn't migration between states within the U.S. continue until all the states are no better (all things considered by the potential migrants) than the states from whence they come? The answer is simply that it does. The question is failing to understand the subjective utility-evaluation of the potential migrants. If someone in a relatively poor state decided that-on balance given his preferences-he would be better off moving to New York, then he would move to New York. There is some tendency for the 'objective' economic circumstances to be damaged in this way. But the U.S. states are not so different, given the various preferences of its many inhabitants, that a dangerously large number of people are likely suddenly to choose to go to what might appear to be a 'better' state as judged by 'objective' economic standards. However, as the Gallup survey shows, that situation is completely different when the whole world is considered. There is a vast pent-up demand to move to the U.S. that would do serious damage to the U.S. as measured by the preferences of its current inhabitants, and by 'objective' standards too.
}

1. Individuals have a prima facie right to immigrate (that is, a right not to be prevented from immigrating).

On the contrary, in a libertarian world people would need to be invited in by property-owners. And without the state all so-called 'public property' would have been owned by the current citizens. Therefore, saying there is a prima facie right to come into a country sounds relevantly and sufficiently as mistaken as saying that people have a prima facie right to enter someone else's land or even house without being invited in. ${ }^{22}$

This is because:

a. Individuals have a prima facie right to be free from harmful coercion.

This cannot be correct: it is sometimes necessary to use "harmful coercion" against violators of liberty (i.e., the violators are reactively made worse off by the use of force or the threat of force). What individuals "have a prima facie right to be free from" is proactive interference with their person and libertarian property. ${ }^{23}$

b. Immigration restrictions are harmful and coercive.

20 Vast numbers seem likely to arrive in a matter of months. When people have the opportunity to escape a poverty-stricken and dangerous country for a rich and safe one, then most of them are unlikely to wait for years. And this could not all be at their own expense, as they would be making use of all the 'public resources' to which the existing population have a prior claim: their taxes have paid for their production and upkeep and they would have already owned them but for state monopolisation.

21 Quotations are from an online version, which does not have the journal pagination: http://www.owl232.net/papers/immigration.htm

22 Of course, as argued, it would solve the problem if there were first to be full libertarian privatisation of all state-owned assets among the existing population. But Huemer 2010 is not advocating that. It is advocating that the borders be opened without this happening.

${ }^{23}$ When the country has not first been fully privatised there will always be some proactive interference: using the property that the existing population would otherwise, and should, own but which the government has claimed. Even invited immigrants will cause negative externalities if 'public property' exists. 
One is not proactively interfered with by being denied access to things that other people own, or should rightfully own, however much one wants or needs them. And immigration controls are (by general intention, at least, and however imperfectly) reactively coercive. Such reactive coercion is in principle defensive and to that extent libertarian.

The argument for free immigration ought to be persuasive to nearly everyone, regardless of ideological orientation.

The argument ought not to be persuasive even to most libertarians; and not to any welfare consequentialists either. ${ }^{24}$

\section{CONCLUSION}

Consider three broad options on the issue of immigration.

1. Privatise everything along libertarian lines among the existing national citizens (who would already own it all, but for the state), and then let liberty and free markets sort things out: this is the only fully libertarian and economically efficient option; but it's not going to happen before most intellectuals become libertarians.

2. Open the state borders and let unlimited numbers of people enter: this would be a libertarian and welfare disaster; but it is so obviously awful (except, apparently, to some well-known libertarians) that it's never going to happen.

3. Have state controls on immigration: this is highly imperfect as regards liberty or welfare; but at least it avoids a national disaster and it can slowly be moved in a more-libertarian direction. And that is what libertarians should be promoting: specific, practical, immigration policies that increase people's liberty and thereby also their welfare. ${ }^{25,26}$

\section{WORKS CITED}

Block, W. E. (1998). "A Libertarian Case for Free Immigration”, Journal of Libertarian Studies 13:2: 167186.

Block, W. \& Callahan, G. (2003). "Is There a Right to Immigration?: A Libertarian Perspective", Human Rights Review, October-December 2003: 46-71.

Caplan, B. (2012). "Why Should We Restrict Immigration?" Cato Journal, 32:1: 5-24.

\begin{abstract}
24 It is necessary to take seriously the Gallup survey and the vast amount of illegal immigration despite huge deterrents, including the very real risk of death in many cases. And one must not conflate the libertarian privatise-among-the-citizens solution with opening the borders in the current situation. In principle, the free market can sort out any problems without serious negative externalities. But there can be nothing like a free market while the state owns almost all of the roads, parks, etc., that the existing populace ought to own.

25 Quoted by Lee Waaks (personal communication, 2nd October 2019) with responses. Stephen Davies: "Fundamentally there is no meaningful difference between free movement within geopolitical borders (a hard fight for 19th century liberals) and free movement that goes across geopolitical borders." In terms of abstract economic theory, they may be the same thing. But in terms of practical reality, the introduction of the latter would be a disaster. In any case, it would be more
\end{abstract}

apposite to observe that, to be consistent, this essay should hold that the former is a similar problem (albeit on a much lesser scale) until all the 'public property' is allocated to its just private owners within the geopolitical borders. And that is true. It is simply not the crux of the debate here, and so was not discussed. "You can only make the argument that there is if you make the political community something that exists above and beyond the autonomous individual[s] and has prior claims upon them." It is the state that "exists above and beyond the autonomous individual[s]". However, by libertarian rights, it has no "prior claims upon them". Rather, they have a claim on it to the property that it has taken by proactive coercion.

${ }^{26}$ Comments from Mark Brady and David McDonagh have improved this essay. No blame can be attached to them for any faults. 
Caplan, B. (2014). "The Swamping that Wasn't: The Diaspora Dynamics of the Puerto Rican Open Borders Experiment", The Library of Economics and Liberty, accessed 15th Dec. 2020: https://www.econlib.org/archives/2014/03/the_swamping_th.html.

Clifton, J. (2012). "150 Million Adults Worldwide Would Migrate to the U.S.", Gallup.com. https://news.gallup.com/poll/153992/150-Million-Adults-Worldwide-Migrate.aspx

Esipova, N. Pugliese, A. \& Ray, J. (2018). "More Than 750 Million Worldwide Would Migrate If They Could" Gallup website, accessed 2nd Dec. 2020: https://news.gallup.com/poll/245255/750million-worldwide-

migrate.aspx?g_source=link_NEWSV9\&g_medium=NEWSFEED\&g_campaign=item_\&g_cont ent=More\%2520Than\%2520750\%2520Million\%2520Worldwide\%2520Would\%2520Migrate\% 2520lf\%2520They\%2520Could

Gregory, A. \& Block, W. E. (2007). "On Immigration: Reply to Hoppe," Journal of Libertarian Studies, 21: 3: $25-42$.

Heumer, M. (2010). "Is There a Right to Immigrate?", Social Theory and Practice, 36:3: 429-61

Lester, J. C. ([2000] 2012). Escape from Leviathan: Libertarianism Without Justificationism. Buckingham: The University of Buckingham Press.

Lester, J. C. ([2011] 2016). Arguments for Liberty: a Libertarian Miscellany. Buckingham: The University of Buckingham Press.

Lester, J. C. (2014). Explaining Libertarianism: Some Philosophical Arguments. Buckingham: The University of Buckingham Press.

Lester, J. C. (2021). "Eleutherological-Conjecturalist Libertarianism: a Concise Philosophical Explanation", PhilPapers: https://philpapers.org/rec/INDNLA.

McCarthy, N. (2018). "Nearly 160 Million People Want To Move To The U.S." Gallup website, accessed $2^{\text {nd }}$ Dec. 2020: https://www.statista.com/chart/10146/150-million-people-would-move-to-the-usif-they-could/.

Migration Watch UK (2019). “Evidential basis for MWUK's '30 Million' claim”, accessed $4^{\text {th }}$ Dec. 2020: https://www.migrationwatchuk.org/briefing-paper/464/evidential-basis-for-mwuks-30-millionclaim.

Miller, D. W. (1994). Critical Rationalism: A Restatement and Defence. Chicago and La Salle, III.: Open Court.

Popper, K. R. ([1963] 1978). Conjectures and Refutations. London: Routledge and Kegan Paul.

Received for publication: $\quad 22.12 .2020$

Revision received: $\quad 22.02 .2021$

Accepted for publication: $\quad$ 06.07.2021

\section{How to cite this article?}

Style - APA Sixth Edition:

Lester, J. C. (2021, July 15). Immigration and libertarianism: Open borders versus directionalism. (Z. Cekerevac, Ed.) MEST Journal, 9(2), 35-44. doi:10.12709/mest.09.09.02.06

Style - Chicago Sixteenth Edition:

Lester, J. C. 2021. "Immigration and libertarianism: Open borders versus directionalism." Edited by Zoran Cekerevac. MEST Journal (MESTE) 9 (2): 35-44. doi:10.12709/mest.09.09.02.06. 
Style - GOST Name Sort:

Lester J. C. Immigration and libertarianism: Open borders versus directionalism [Journal] // MEST Journal / ed. Cekerevac Zoran. - Belgrade - Toronto : MESTE, July 15, 2021. - 2 : Vol. 9. - pp. 35-44.

Style - Harvard Anglia:

Lester, J. C., 2021. Immigration and libertarianism: Open borders versus directionalism. MEST Journal, 15 July, 9(2), pp. 35-44.

Style - ISO 690 Numerical Reference:

Immigration and libertarianism: Open borders versus directionalism. Lester, J. C. [ed.] Zoran Cekerevac. 2, Belgrade - Toronto : MESTE, July 15, 2021, MEST Journal, Vol. 9, pp. 35-44. 